\title{
Waterpipe Smoking Among Youth and Socioeconomic Status: A Cross-Sectional Study of Students in Public Versus Private Universities
}

\author{
Asena Caner ( $\nabla$ asena.caner@gmail.com ) \\ TOBB University of Economics and Technology \\ Hilal Özcebe \\ Hacettepe University
}

\section{Research Article}

Keywords: Waterpipe smoking, Shisha, Hookah, University student, Prevalence, Young adult, Turkey

Posted Date: June 25th, 2021

DOl: https://doi.org/10.21203/rs.3.rs-621527/v1

License: (c) (1) This work is licensed under a Creative Commons Attribution 4.0 International License. Read Full License 


\section{Abstract}

\section{Background}

Waterpipe smoking has become a global public health problem as its popularity increased over time, especially among youth. This study aims to examine waterpipe smoking patterns of university students in Ankara, Turkey, and compare the patterns in public and private universities, which have different economic and social environments. Students in these two types of universities differ, on average, in socioeconomic background and access to financial resources.

\section{Methods}

The survey was conducted among public $(n=2685)$ and private $(n=2485)$ university students via an online questionnaire. Logistic regressions (on the full sample and on the sample that excludes students who initiate before age 18) were used to test the association between ever using waterpipe and respondent characteristics such as age, gender, university type, living arrangements, and source of income. Descriptive statistics on consumption pattern (age at first use, use within last month, location of use, availability of waterpipe venues, whether it is usually shared, reasons for use, and harm perceptions) were also generated. Moreover, never, ever, and current user prevalence rates by age at first use were estimated for waterpipe and cigarettes.

\section{Results}

$69 \%$ of students in private and $59 \%$ of students in public universities $(p<0.001)$ were ever smokers of waterpipe. Being older, male, private university student, living alone or having roommate(s), as well as financial resources such as having access to a car, having income from work or family were associated with ever using waterpipe. Although more than half (68-70\%) of ever users tried waterpipe before age 18 , risk continued in university and $41-46 \%$ of those who tried before 18 were current users in university. For women who had abstained from waterpipe until university age, the risk of waterpipe use was higher in private than in public universities.

\section{Conclusions}

Waterpipe smoking has increased and is highly common among university students. Students with higher socioeconomic status are at higher risk. There is an urgent need to implement the new creative interventions based on the WHO Framework Convention on Tobacco Control to prevent the young people from waterpipe smoking after 18 years old.

\section{Background}

The consumption of tobacco in a waterpipe (also known as hookah or shisha) is a serious public health problem that is known to be associated with several adverse health outcomes (1). It originated in Middle Eastern countries and has existed for centuries (2). Unlike other tobacco products, waterpipe is often used 
communally and in a prolonged time period (3). As most of the consumption is intermittent, users rarely consider themselves as under risk of addiction or severe health consequences (3).

Waterpipe smoking by the youth is especially worrying because of the economic burden it can generate in the long term by reducing productivity and imposing health costs. Unfortunately, waterpipe smoking has increased its popularity among adolescents and youth in the world $(4,5)$. The prevalence of waterpipe smoking is much higher in Eastern Mediterranean and European countries than the other parts of the world, and also much higher among young people than adults. Studies conducted in Eastern Mediterranean countries report the prevalence to vary between $14.9 \%$ to $65.3 \%$ in years 2002 to 2014 (6).

In Turkey, tobacco control is an important part of public health policy. The first law in 1996 aimed to protect people from tobacco smoke in governmental buildings, and health and educational institutions. The ban was broadened in 2008 to include school premises, all tourism and hospitality workplaces and commercial taxis. Then, the hospitality sectors started to promote waterpipe service especially to young people and tobacco smokers at cafés, which were called "waterpipe café"s. The industry used the common belief in the community that waterpipe smoking is less harmful than cigarette smoking because the harmful particles of waterpipe smoke is filtered into the water. They also offered waterpipe with flavored tobacco to enrich taste and smell. Young people began to enjoy smoking waterpipe with their friends for a couple of hours and waterpipe cafes became popular locations for socialization (7-9). The promotion of waterpipe to young people has caused an increase in the prevalence of its use among young people. According to the Global Youth Tobacco Survey (2017) in Turkey, the percentage of waterpipe ever-users was $24.6 \%$ among $13-15$ years old adolescents (31.6\% for boys and $17.5 \%$ for girls) (10). The prevalence of water pipe ever-users among university students was between $18.9 \%$ to $48 \%$ according to age and gender in the country $(11-13)$.

Smoking behavior is affected by individual, social, institutional and political factors; being male and having a relative/friend who is a smoker are important determinants for smoking in adolescents and young adults. Financial resources of the person also shape preferences, lifestyle and habits (14-16). It is already known that the prevalence of ever using waterpipe has been rising among university students $(17,18)$, but there is no research to show how the economic and social environment of universities affects waterpipe smoking among university students. This study addresses the knowledge gaps in the literature on the patterns of waterpipe smoking among university students, and aims to help advance evidence-based waterpipe control. The objective of our study is to examine the rates of waterpipe tobacco smoking initiation, and frequency, reasons, and place of smoking in this group. The main contribution is to compare students in two types of universities, namely private foundation universities and public universities. We argue that the two groups have different socio-economic characteristics, which factor into their pattern of waterpipe smoking.

\section{Methods}

\section{Study Design and Sampling}

In Turkey, there are currently 129 public (state) universities and 72 private foundation universities (19). Public universities require a nominal payment for registration (284-591 TL (about 60.24-125.35 USD) per year depending on the field of study in the 2018-2019 academic year) (20). The tuition of private foundation 
universities, however, can be quite high. This study was conducted in two private foundation universities and one state university. In 2018, the tuition of these private foundation universities was 37,120 - 52,500 TL (7,873 - 11,135 USD), depending on the field of study. For comparison, gross domestic product per capita in 2018 was 46,167 TL (9,792 USD) (21). Only a small number of students in private foundation universities receive financial assistance towards tuition. The majority of them are required to pay the tuition, which can be as high as (or higher than) the per capita income in the country. This requirement keeps many low-income students away from private universities.

The data used in this paper were collected via an online survey of students from two private foundation universities and one public university in Ankara, Turkey, during the 2018-2019 academic year, when there were 11,014 (5,881 male and 5,133 female) and 5,245 (2,702 male and 2,543 female) undergraduate students in the two private foundation universities, and 35,331 (14,894 male and 20,437 female) undergraduate students in the public university. In Ankara, there were a total of 26,781 male and 26,674 female students in private universities and 72,627 male and 80,607 female students in public universities (19).

A pilot testing of the survey was done to ensure that the questions are clear and the survey runs smoothly. Then, the student affairs or related administrative departments of the universities were requested to send the online survey website link to enrolled students through registered student email addresses. Permission was obtained by the authors from the Ethics Committees of the respective universities prior to data collection[1]. Informed consent was obtained from all participating students; no student was under 18 . The total number of students who participated in the survey were 1,362 and 1,215 in the private universities, and 2,731 in the public university. All methods (including data collection and analysis) were carried out in accordance with relevant guidelines and regulations.

Students from different schools and departments of the universities participated in the survey. About $36 \%$ were from the School of Engineering, 27\% from the School of Economic and Administrative Sciences, $15 \%$ from the School of Science and Letters, $6 \%$ from the School of Fine Arts, Design, and Architecture, $4 \%$ from the Law School, 3\% were from the School of Nursery, $2.9 \%$ were from the School of Dentistry, $2.6 \%$ were from the School of Pharmacy.

The questionnaire consisted of 46 questions and collected information about demographic and socioeconomic characteristics and tobacco (waterpipe and cigarette) consumption patterns.

\section{Measurements}

\section{Demographics and waterpipe use pattern}

Demographic characteristics data included gender and age. Waterpipe use status was determined based on ever using it, relying on the question "Have you ever smoked waterpipe?", since ever using waterpipe is a major risk factor of using tobacco products in the future. If participants had ever smoked a waterpipe, their patterns of use were surveyed (i.e., age at initiation, whether used in the last month, location of use, the number of waterpipe venues close by, whether waterpipe is usually shared, why they like waterpipe, and relative risk perception). Waterpipe use among friends and own cigarette use were also asked. In some analyses, current use was also considered. 
Family income was not asked in the survey, since the income variable is difficult to precisely measure in such surveys. Students may be unaware of or reluctant to reveal true income. Instead, the survey included several other questions to help assess socioeconomic status and the student's access to financial resources: Whether the student had access to a car (with or without ownership); Living arrangement of the student (living in a dormitory, living alone (outside of dormitory), living at home with family, or sharing the residence with friends); Source of income of the student (Family, scholarship, work); Sufficiency of income (not sufficient, barely sufficient, sufficient).

\section{Statistical analysis}

Descriptive statistics (percentages and numbers of observations) were reported for never and ever users of waterpipe in private and public universities. Among ever users of waterpipe, descriptive characteristics on the patterns of use were presented. Next, descriptive statistics were given on waterpipe and cigarette smoking status (ever, current, and never use) by initiation before or during university. Moreover, descriptive statistics were reported to compare different groups by smoking status (never smokers, waterpipe only, cigarette only, and dual users). Also, p-values were used to test whether students in private universities are different from those in public universities.

Logistic regressions were used to estimate (adjusted) odd ratios (OR) for ever-waterpipe smoking on the full sample and on a sample that excludes students who initiate before age 18. Multinomial logistic regression yielded relative risk ratios (RRR) for four different smoking behaviors (never smokers chosen as the base category). In all models, two sets of estimates were obtained: first, with only the explanatory variables and, second, with the private university dummy variable added as an explanatory variable and interacted with all explanatory variables, in order to detect whether the effects differ across the two types of universities. In reporting the results of models with the interaction terms, only the estimates of the interaction terms were reported.

[1] TOBB ETÜ Human Research Review Board Decision No. 2018 February 01-1

Non-Interventional Clinical Research Ethics Board of Hacettepe University, 2018 April 10; G0 18/393-39

\section{Results}

Overall, there were 2,485 private and 2,685 public university students in our sample. In private universities $76.3 \%$ of males and $61.4 \%$ of females, and among public university students $72.7 \%$ of males and $49 \%$ of females were ever users of waterpipe. For both genders, the type of university matters for ever using waterpipe ( $p$-values $<0.05$ and $<0.001$ respectively). Similarly, within age groups, the percentages of ever users are higher in the private universities (with the exception of the oldest age group) (Table 1).

Compared to public university students, a higher share of private university students has access to a car (51.7\% versus $35.8 \%)$, live at home with family (51.6\% versus $46.4 \%)$, rely on their families for financial support (71.5\% versus $65.1 \%)$, and have sufficient income (51.9\% versus $35.1 \%)$. For all categories of these 
socioeconomic variables (except for working to make a living), the type of university matters for ever using waterpipe (Table 1).

Private university students stated that waterpipe consumption is common among their friends. Compared to public university students, a lower share of private university students said that currently none of their friends use waterpipe (18\% versus $24.6 \%$ ). Moreover, a higher share of private than public university students are ever cigarette smokers (69.7\% versus 63.6\%) (Table 1$)$.

Patterns of waterpipe smoking among respondents who have ever smoked waterpipe ( $n=1,699$ in private, $\mathrm{n}=1,582$ in public universities) are shown in Table 2 . In this group, the majority (63.2\% in private universities and $62.6 \%$ in public university) used it first when they were in ages $14-18$ ( $p>0.05) ; 14.8 \%$ (in private universities) and $8.7 \%$ (in public university) of ever users stated that they smoked waterpipe within the last month $(p<0.001)$.

Waterpipe is most often ( $>90 \%$ ) used outside of home (at a narghile cafe or at other cafes, restaurants, or tea houses) and more than $85 \%$ of the students usually shared their waterpipe $(p=0.101)$. Compared to public university students, more opportunities (a higher number of waterpipe offering venues) exist for private university students where they usually spend time (close to their university) $(p<0.001)$ (Table 2).

More than half of the students in both types of institutions (59.2\% and $60.9 \%)$ think that waterpipe is more harmful than cigarettes. Close to $20 \%$ think that they are equally harmful $(p>0.05)$. Students enjoy waterpipe for several reasons. The sensory charms of waterpipe are important for youth. Respondents in private and public universities agreed that they enjoy the aroma (more than $75 \%)$, they find it pleasurable $(51.8 \%$ and 42.7\%), and enjoy that its smoke does not hurt throat (31.4\% and $31.0 \%$ ). Students also stated that they like waterpipe because it facilitates socialization ( $44.7 \%$ versus $33 \%, p<0.001)$, it can be shared with friends ( $31.0 \%$ versus $25.0 \%, p<0.001)$, and it makes conversation more fun $(27.8 \%$ versus $22.7 \%, p=0.001)$. A higher share of private university (versus public university) students emphasized the feelings of enjoyment for waterpipe smoking (Table 2).

Among current users of waterpipe who revealed spending information $(n=752)$, the average monthly spending on waterpipe was statistically significantly higher among private university students (42 TL) than among public university students (29.6 TL) (not tabulated).

Table 1: Demographics of survey participants by university type and waterpipe use status 
Private

Ever Never Total

$\%$

$\%$

$\mathrm{n}$

$\%$

76.3

23.7

1,289

51.9

$61.4 \quad 38.6 \quad 1,196$

48.

Public

p

Gender

Male

Female

Age group

18-19

59.2

40.8

Ever

Never Total

20-21

22-23

24 or older

Has a car

Yes

No

\section{Living arrangement}

In dormitory

$73.1 \quad 26.9$

1,126

51.7

67.7

32.3

895

$35.8 \quad 0.008$

$64.3 \quad 35.7 \quad 1,052$

48.3

$54.4 \quad 45.6$

1,607

$64.2<0.001$

Lives alone

Lives with family

Has roommate(s)

\section{Source of income*}

Family support

Scholarship

Work
65.5

$65.5 \quad 34.5$

90.1

68.0

82.2

$\begin{array}{lll}70.6 & 29.4 & 1,716 \\ 60.4 & 39.6 & 490\end{array}$

60.4

$21.7 \quad 92$

\section{Perception of income sufficiency}

\begin{tabular}{lccccccccc} 
Not sufficient & 81.9 & 18.1 & 144 & 6.1 & 61.0 & 39.0 & 418 & 16.1 & $<0.001$ \\
\hline Barely sufficient & 73.7 & 26.3 & 982 & 41.9 & 60.4 & 39.6 & 1,265 & 48.8 & $<0.001$ \\
\hline Sufficient & 64.2 & 35.8 & 1,216 & 51.9 & 56.9 & 43.1 & 911 & 35.1 & 0.001 \\
\hline Waterpipe use among friends & & & & & & & & \\
\hline Most or all & 78.6 & 21.4 & 406 & 17.3 & 69.7 & 30.3 & 416 & 16.0 & $\mathbf{0 . 0 0 4}$ \\
\hline Some & 70.7 & 29.3 & 1,513 & 64.6 & 62.4 & 37.6 & 1,538 & 59.3 & $<0.001$
\end{tabular}




$\begin{array}{llllllllll}\text { None } & 55.5 & 44.5 & 422 & 18.0 & 45.0 & 55.0 & 638 & 24.6 & 0.001\end{array}$

\section{Cigarette smoking}

\begin{tabular}{llllllllll}
\hline Ever & 85.9 & 14.1 & 1,732 & 69.7 & 79.6 & 20.4 & 1,707 & 63.6 & $<0.001$ \\
\hline Never & 30.4 & 69.6 & 753 & 30.3 & 23.3 & 76.7 & 978 & 36.4 & $\mathbf{0 . 0 0 1}$
\end{tabular}

Notes: The p-value refers to the chi-square test where the null hypothesis is no relationship between the type of the university and waterpipe use status.

$\left.{ }^{\star}\right)$ More than one income source could be selected.

Table 2. Patterns of waterpipe smoking among respondents who have ever smoked waterpipe 
Private University Public University p-value

$\begin{array}{llll}n & \text { n } & \text { n }\end{array}$

Age at first use

0.133

Younger than 14

171

10.1

133

8.4

Ages 14-18

1,074

63.2990

62.6

Older than 18

454

26.7

459

29.0

\section{Use within the last month}

Yes

\section{Location of waterpipe use}

$\begin{array}{llll}253 & 14.8 & 137 & 8.7\end{array}$

$\begin{array}{llll}1,454 & 85.2 & 1,445 \quad 91.3\end{array}$

\begin{tabular}{|c|c|c|c|c|c|}
\hline At home only & 21 & 3.8 & 26 & 5.7 & \\
\hline Outside of home only & 489 & 87.9 & 395 & 87.0 & \\
\hline Both at home and outside of home & 46 & 8.3 & 33 & 7.3 & \\
\hline Number of waterpipe venues close by & & & & & $<0.001$ \\
\hline None & 224 & 13.5 & 359 & 23.2 & \\
\hline $1-3$ venues & 677 & 40.8 & 593 & 38.3 & \\
\hline 4 or more venues & 758 & 45.7 & 598 & 38.6 & \\
\hline Waterpipe sharing (usually) & & & & & 0.101 \\
\hline No & 78 & 14.4 & 48 & 10.9 & \\
\hline Yes & 465 & 85.6 & 394 & 89.1 & \\
\hline \multicolumn{6}{|l|}{ Reasons for waterpipe use* } \\
\hline Enjoy the aroma & 1293 & 75.3 & 1197 & 75.5 & 0.911 \\
\hline Pleasurable & 889 & 51.8 & 677 & 42.7 & $<0.001$ \\
\hline Facilitates socialization & 767 & 44.7 & 524 & 33.0 & $<0.001$ \\
\hline Smoke does not hurt throat & 539 & 31.4 & 492 & 31.0 & 0.818 \\
\hline Can be shared with friends & 533 & 31.0 & 397 & 25.0 & $<0.001$ \\
\hline Makes conversation more fun & 478 & 27.8 & 360 & 22.7 & 0.001 \\
\hline Part of traditional culture & 339 & 19.7 & 249 & 15.7 & 0.002 \\
\hline Makes nice visual in social media & 306 & 17.8 & 285 & 18.0 & 0.912 \\
\hline Nice ambience and food & 304 & 17.7 & 220 & 13.9 & 0.003 \\
\hline
\end{tabular}




\begin{tabular}{lccccc} 
Shares in social media invoke curiosity & 185 & 10.8 & 143 & 9.0 & 0.091 \\
\hline Waterpipe or cigarettes more harmful & & & & 0.335 \\
\hline Waterpipe is more harmful & 935 & 59.2 & 915 & 60.9 & \\
\hline Both are equally harmful & 274 & 17.4 & 275 & 18.3 \\
\hline Cigarettes are more harmful & 245 & 15.5 & 202 & 13.4 \\
\hline Do not know & 125 & 7.9 & 110 & 7.3
\end{tabular}

Note: Sum of n's may differ across categories since not all questions are answered by all participants. (*) More than one reason could be selected.

The estimates presented in Table 3 show that in both private and public universities, being male and being older were positively associated with ever use of waterpipe. In the public university, having access to a car increased the risk (OR 1.367). Compared to living in the dormitory, living alone (OR 3.187 and 2.132) or having roommate(s) (OR 1.922 and 1.673) increased the risk in both types of universities. Living with family increased risk in the public university (OR 1.258). Compared to living on a scholarship, being financially supported by the family increased risk in the private universities (OR 1.658) and earning income from work substantially increased the risk for all students (OR 1.751 and 2.101).

Table 3. Ever smoked waterpipe: Logistic regression estimates (Odds ratios) 


\begin{tabular}{|c|c|c|c|c|}
\hline & $\begin{array}{l}\text { Private } \\
\text { university }\end{array}$ & $\begin{array}{l}\text { Public } \\
\text { university }\end{array}$ & All & $\begin{array}{l}\text { Interaction effect with } \\
\text { "Private" }\end{array}$ \\
\hline \multirow[t]{2}{*}{ Private university } & & & $1.574^{\star \star \star}$ & \\
\hline & & & $(0.105)$ & \\
\hline \multicolumn{5}{|l|}{ Base category: Female } \\
\hline \multirow[t]{2}{*}{ Male } & $2.231^{\star \star \star}$ & $2.499 * \star \star$ & $2.359 \star \star \star$ & 0.893 \\
\hline & $(0.223)$ & $(0.237)$ & $(0.161)$ & $(0.123)$ \\
\hline \multicolumn{5}{|c|}{ Base category: Ages 18-19 } \\
\hline \multirow[t]{2}{*}{ Ages $20-21$} & $1.334^{\star \star}$ & $1.666^{\star \star \star}$ & $1.502^{\star \star \star}$ & 0.801 \\
\hline & $(0.167)$ & $(0.222)$ & $(0.136)$ & $(0.146)$ \\
\hline \multirow[t]{2}{*}{ Ages 22-23 } & 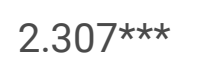 & 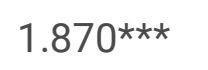 & $2.039 \star \star \star$ & 1.233 \\
\hline & $(0.324)$ & $(0.264)$ & $(0.201)$ & $(0.246)$ \\
\hline \multirow[t]{2}{*}{ Ages 24 or older } & 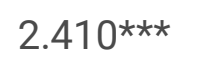 & $2.482^{\star \star \star}$ & $2.389 * \star \star$ & 0.971 \\
\hline & $(0.523)$ & $(0.448)$ & $(0.325)$ & $(0.274)$ \\
\hline \multicolumn{5}{|l|}{ Base category: No car } \\
\hline \multirow[t]{2}{*}{ Has a car } & 1.116 & $1.367 \star \star \star$ & $1.237 \star \star \star$ & 0.816 \\
\hline & $(0.116)$ & $(0.137)$ & $(0.0890)$ & $(0.118)$ \\
\hline \multicolumn{5}{|l|}{$\frac{\text { Base category: Lives in }}{\text { dormitory }}$} \\
\hline \multirow[t]{2}{*}{ Home with family } & 0.996 & $1.258^{\star \star}$ & $1.153^{*}$ & 0.792 \\
\hline & $(0.113)$ & $(0.125)$ & $(0.0854)$ & $(0.120)$ \\
\hline \multirow[t]{2}{*}{ Lives alone } & 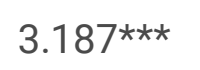 & $2.132^{\star \star \star}$ & 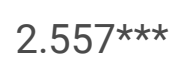 & 1.495 \\
\hline & $(1.032)$ & $(0.530)$ & $(0.496)$ & $(0.610)$ \\
\hline \multirow[t]{2}{*}{ Has roommate(s) } & $1.922^{\star \star \star}$ & $1.673^{\star \star \star}$ & $1.708^{\star \star \star}$ & 1.149 \\
\hline & $(0.470)$ & $(0.269)$ & $(0.226)$ & $(0.336)$ \\
\hline \multicolumn{5}{|c|}{ Base category: Scholarship_. } \\
\hline \multirow{2}{*}{$\begin{array}{l}\text { Income source: Family } \\
\text { Support }\end{array}$} & $1.658^{\star \star \star}$ & 1.126 & $1.320 * \star \star$ & $1.473^{\star \star}$ \\
\hline & $(0.204)$ & $(0.120)$ & $(0.105)$ & $(0.240)$ \\
\hline \multirow[t]{2}{*}{ Income source: Work } & $1.751^{*}$ & $2.101^{\star \star \star}$ & $2.072^{\star \star \star}$ & 0.833 \\
\hline & $(0.554)$ & $(0.458)$ & $(0.370)$ & $(0.320)$ \\
\hline Observations & 2184 & 2352 & 4536 & 4536 \\
\hline
\end{tabular}


Notes: The first two columns show estimates of odds ratios for private and public university students separately. The third column shows the estimates for the entire sample, adding the "Private" dummy variable to the regression. The last column shows the estimates of the interaction terms (when all explanatory variables are interacted with the "Private" dummy). Standard errors of coefficient estimates are shown in parentheses. $* p<0.10, * \star p<0.05, * * * p<0.01$.

In Table 3, as shown in the third column, which shows the estimates for the entire sample, being in a private university increases the risk of ever using (OR 1.574), after controlling for other factors. In the fourth column, all explanatory variables are interacted with the "Private" dummy and only the estimates of the interaction terms are presented. Private university students who rely financially on family support are at a higher risk (OR 1.473), relative to public university students. The other interaction terms are statistically insignificant, but it is noteworthy that being female or having a car has higher risk in public universities, whereas living alone or having roommate(s) has higher risk in private universities, although at low levels of statistical significance.

Table 4: Waterpipe and cigarette use status by university type and age at first use

\begin{tabular}{|c|c|c|c|c|c|c|c|c|c|c|c|c|}
\hline & Privat & univers & & & & & Public & univers & & & & \\
\hline & $\begin{array}{l}\text { Stude } \\
\text { water }\end{array}$ & $\begin{array}{l}\text { ts who } \\
\text { pe }\end{array}$ & ried & & & & $\begin{array}{l}\text { Stude } \\
\text { water }\end{array}$ & $\begin{array}{l}\text { ts who } \\
\text { pe }\end{array}$ & ried & & & \\
\hline & Befor & & After & & Total & & Befor & & After & & Total & \\
\hline & $n$ & $\%$ * & $n$ & $\%$ * & $n$ & $\% \star \star$ & $n$ & $\%$ * & $n$ & $\%$ * & $n$ & $\%$ \%* \\
\hline $\begin{array}{l}\text { Never } \\
\text { user of } \\
\text { either }\end{array}$ & & & & & 524 & 22.0 & & & & & 750 & 29.1 \\
\hline Past user & & & & & 711 & 29.9 & & & & & 849 & 32.9 \\
\hline $\begin{array}{l}\text { Waterpipe } \\
\text { only }\end{array}$ & 105 & 61.8 & 65 & 38.2 & 170 & 7.2 & 114 & 60.6 & 74 & 39.4 & 188 & 7.3 \\
\hline $\begin{array}{l}\text { Cigarette } \\
\text { onlyna }\end{array}$ & - & & - & & 154 & 6.5 & - & & - & & 245 & 9.5 \\
\hline Both & 271 & 70.0 & 116 & 30.0 & 387 & 16.3 & 268 & 64.4 & 148 & 35.6 & 416 & 16.1 \\
\hline $\begin{array}{l}\text { Current } \\
\text { user }\end{array}$ & & & & & 1142 & 48.0 & & & & & 978 & 38.0 \\
\hline $\begin{array}{l}\text { Waterpipe } \\
\text { only }\end{array}$ & 117 & 68.0 & 55 & 32.0 & 172 & 7.2 & 94 & 69.1 & 42 & 30.9 & 136 & 5.3 \\
\hline $\begin{array}{l}\text { Cigarette } \\
\text { only }\end{array}$ & 546 & 77.2 & 161 & 22.8 & 707 & 29.7 & 477 & 75.0 & 159 & 25.0 & 636 & 24.7 \\
\hline Dual user & 206 & 78.3 & 57 & 21.7 & 263 & 11.1 & 170 & 82.5 & 36 & 17.5 & 206 & 8.0 \\
\hline Total & 1245 & & 454 & & 2377 & & 1123 & & 459 & & 2577 & \\
\hline
\end{tabular}


Notes: *row percentage, ** column percentage, na: not available

Among private university students $22 \%$ are never users, $29.9 \%$ are past users, and $48 \%$ are current users of waterpipe (Table 4). The percentages are $29.1 \%, 32.9 \%$, and $38 \%$ for public university students. In the overall, a higher share of students tried waterpipe before age 18 than after. Among ever users of waterpipe, $29.5 \%$ of private university students tried it after age $18((65+116+55+57) /(170+387+172+263)=293 / 992)$ and $31.7 \%$ of public university students tried it after age $18((74+148+42+36) /(188+416+136+206)=300 / 946)$.

Among ever users of waterpipe in private universities $(170+387+172+263=992), 70.5 \%$ tried it before age 18 and $46.2 \%$ (323/699) of those who tried before age 18 are current users. Among ever users of waterpipe in public universities, $68.3 \%$ tried it before age 18 , and $40.9 \%$ (264/646) of those who tried before age 18 are current users.

In order to investigate the characteristics of students who try waterpipe after age 18 (at university), we estimate the same logistic regression in a sample of students who have never smoked waterpipe before age 18 (Table 5). Male (OR 1.743) and older students (OR 3.419-7.5) are at higher risk of use after age 18. These groups are at greater risk in public universities than in private universities (interaction terms $O R s<1$ ). Women are at higher risk in private universities. Although not precisely estimated, having a car (OR 1.152) increases the risk for all students, but more so for public university students (interaction term $O R=0.852<1$ ). Living alone (OR 2.638) or having roommate(s) (OR 1.675) increases the risk mainly in private universities, whereas living with family (OR 1.287) increases the risk in the public university. Being financially supported by the family (OR 1.353) increases risk in the private universities, while earning income from work (OR 2.645) substantially increases the risk in the public university.

Table 5. Logistic regression of ever using waterpipe (after excluding students who tried waterpipe before age 18) 


\section{Private university}

Private university

Base category: Female

Male

$1.469 * \star \star$

(0.202)

Base category: Ages 18-19

Ages 20-21

Ages 22-23

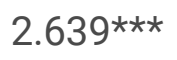

(0.562)

$5.063^{\star \star \star}$

(1.129)

Ages 24 or older

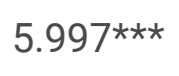

(1.780)

Base category: No car

Has a car

1.069

(0.154)

Base category: Lives in dormitory

\begin{tabular}{lllll} 
Lives with family & 0.909 & $1.287^{*}$ & 1.096 & 0.706 \\
\hline Lives alone & $(0.144)$ & $(0.191)$ & $(0.118)$ & $(0.154)$ \\
& $2.638^{\star *}$ & 1.206 & $1.761^{\star *}$ & 2.188 \\
\hline Has roommate(s) & $(1.039)$ & $(0.422)$ & $(0.449)$ & $(1.152)$ \\
\hline & $1.675^{\star}$ & $1.501^{\star}$ & $1.559 * *$ & 1.116 \\
\hline & $(0.521)$ & $(0.327)$ & $(0.273)$ & $(0.424)$
\end{tabular}

Base category:

Scholarship.

Income source: Family

Support

$\begin{array}{lllll} & (0.230) & (0.200) & (0.148) & (0.257) \\ \text { Income source: Work } & 1.508 & 2.645^{\star \star \star} & 2.244^{\star \star \star} & 0.570 \\ & (0.608) & (0.747) & (0.508) & (0.280) \\ \text { Observations } & 1076 & 1366 & 2442 & 2442 \\ & & \text { Page } 14 / 22 & & \end{array}$


Notes: See Notes to Table 3.

A breakdown into four categories (never smokers, waterpipe smokers, cigarette smokers, and dual smokers) yields additional evidence to support our results. Appendix Table A1 shows that ever users of waterpipe, cigarettes, or both, have different characteristics from never users. Similar to the results in Tables 3 and 5, Appendix Table A2 shows that compared to never smokers, women in private universities were at higher risk of waterpipe use than men (RRR for men 0.651). For public university students, having a car increased the risk of being a dual user (RRR 0.738). Being older (RRR 1.5-2.7 relative to ages 18-19), living alone or having roommate(s) (RRR 2.2-3.18 relative to living in dorm), relying on family support, having earnings from own work (RRR 1.4-2.3 times relative to having a scholarship) increased the risk of being a dual user for both private and public university students. Having family as the main source of financial support increased the risk of using tobacco products among private university students more than it did for public university students.

\section{Discussion}

To the best of our knowledge, this study offers the first evidence of the differences in the pattern of waterpipe use in private foundation versus public universities. Turkey provides us with an ideal setting, since students in these two types of higher education institutions are different, on average, in their socioeconomic background and their access to financial resources. This study exploits this setting to contribute to the literature on the factors that are associated with waterpipe use among youth. The main finding of this study is that although some common factors affect ever using waterpipe in both public and private universities, access to financial resources emerged as a key factor in determining risk.

In public universities, $70.9 \%$ of students are ever users and 38\% are current users of waterpipe; whereas the percentages are higher at $78 \%$ and $48 \%$ in private universities, respectively. Almost one out of two students who tried waterpipe is a current smoker. These figures are in sharp contrast to evidence from Turkish GATS data that in ages 15 and older (a different population than the one in this study) the current use prevalence decreased from $2.3 \%$ in 2008 to $0.8 \%$ in 2012 (22).

Several studies have reported that the prevalence of waterpipe use among youth is quite high in the Middle Eastern countries (33.4\% ever use, 24.4\% current use in Palestinian universities ( $n=1891)(23) ; 21.1 \%$ current use (only waterpipe), 11.3\% (both cigarettes and waterpipe) ( $n=1964)$ in Beirut, Lebanon (24); $25.9 \%$ current use among medical students in Lebanon ( $n=191)(25) ; 61.1 \%$ ever use among 548 university students in Jordan (26); the pooled prevalence of 37 relevant studies was $25 \%$ ever use in Iran (27)). Interest in waterpipe use has been rising in the western part of the world, with prevalence estimates lying in a wide range $(66.0 \%$ ever use in the UK universities $(n=2217)(28)$; ever use rates $18.2 \%$ in ages $18-21$ and $16.9 \%$ in ages $22-24$ in the US PATH study 2013-2014 (3)). A study that assessed the popularity of waterpipe found that in Australia, Canada, the UK, and the USA internet search queries increased steadily between 2004 and 2013 (29). Cross sectional studies in Turkey yielded various estimates; $32.7 \%$ were current users in a Turkish university 
$(\mathrm{n}=645)(11) ; 18.9 \%$ of first grade and $24.5 \%$ of fourth grade students from eight universities were current users ( $n=5221)(12) ; 48 \%$ of males and $20.5 \%$ of females in a Turkish university were ever users ( $n=339)(13)$. Our results indicate much higher prevalence rates than declared in these international and earlier national studies.

This study finds that, although the majority of students who have ever used waterpipe tried it before age 18, the risk of using it continues during the time at university. Among ever users of waterpipe, $29.5 \%$ of private and $31.7 \%$ of public university students tried it after age 18 (at university). Moreover, the risk increased with seniority among students, consistent with earlier studies on Turkey (in 8 public universities, between freshman and senior years, ever use rates increased from $48.9 \%$ to $63.7 \%$ for males and $31.4 \%$ to $42.6 \%$ for females ( $n=5221)$ (12); from $43.0 \%$ to $56.5 \%$ for males and $14.6 \%$ to $32.1 \%$ for females $(n=339)(13)$.

This study finds that the prevalence of ever using waterpipe is higher among men (74.6\%) than women (54.4\%), as in earlier national studies on adolescents and youth $(12,13)$. The relative popularity among men can be related to the perception of smoking, in general, and waterpipe smoking, in particular, as a traditional masculine behavior (11). Among women university students, although the rates are lower than those observed in Eastern Mediterranean countries (30), they are still quite high (for example, $20 \%$ were current users (11) and $35 \%$ were ever users (12)).

Global statistics indicate that the popularity of waterpipe smoking has risen faster among women than men (31-33). For example, in Afghanistan, the prevalence of ever using waterpipe was recently estimated as $54.1 \%$ for male and much higher $81.8 \%$ for female university students (34). In some countries, waterpipe smoking has become the leading form of tobacco use among young women $(35,36)$. One reason is that it is a more acceptable form of female smoking than cigarettes; also, it is a sign of hospitality (37). Another reason may be the feeling of emancipation and empowerment it creates among women by giving them the freedom to participate in a traditionally male-dominant environment and to make their own decisions (3840). In addition, tobacco and waterpipe smoking among women is perceived as a charming behavior $(41,42)$. Waterpipe may also be viewed by females as a sign of social status, since it is viewed as luxurious and available only to those who can afford it (43). In this study, ever use rates among women were $61.4 \%$ (private) and $49 \%$ (public). An important finding of this study is that, among women who have abstained from waterpipe until university age, the risk of waterpipe use is higher in private than in public universities, which may be related to the greater availability of waterpipe to private university students. Young women in Turkey are therefore susceptible to similar risks about waterpipe smoking as their peers in neighboring countries.

In this study, the main reason for the popularity of waterpipe among university students is its sensory charms. Waterpipe smoke yields pleasure without burning the throat and the aroma is enjoyable, as found in earlier studies $(44,45)$. Moreover, waterpipe is enjoyed because it facilitates socialization, it is shared with friends, and makes conversation more fun $(43,46)$. Similar results are reported in the western countries (waterpipe defined as a cool and relaxing by adolescents in Sweden (47) and youth in the UK (46)).

The consumption of waterpipe outside of home, at cafes, restaurants, or tea houses is popular among both public and private university students in Turkey. Waterpipe retail venues (cafes, tea houses) have been 
flourishing in popular spots and are in close proximity to students (around campuses), providing easy access to students. Also, such places are more abundant in locations close to private than public university students. It is also observed that compared to living in a dormitory, which is a more controlled environment, living alone or having roommate(s) increased the risk in both types of universities. Accessibility to waterpipe cafes is an important mediator that enables students to experiment waterpipe smoking with their friends after school hours and constitutes a crucial public health problem $(5,46,48-51)$.

Unlike earlier studies that report lower perceived harm $(45,52,53)$, this study finds that more than half of the students think waterpipe is more harmful than cigarettes, whereas about $13-15 \%$ think the opposite and close to $20 \%$ think the two are equally harmful. Evidently, students have learned about the harmful effects of waterpipe smoking; however, being better informed does not prevent consumption, as $38-48 \%$ were found to be current users.

As in other countries, availability and affordability of waterpipe cafes in Turkey contribute to waterpipe smoking, especially among young women $(33,39,54)$. One of the most important results of this study is that the prevalence of ever using waterpipe is higher among private than public university students. This result can be linked to the non-negligible cost of waterpipe use at commercial venues such as cafés or tea houses, where food and drinks are served in addition to waterpipe. Waterpipe use may be quite a burden on a student's meager budget. A study on Jordan reported that student income (being in the upper middle income group) is significantly associated with ever use of waterpipe (26). As explained before, private universities charge a substantial amount of tuition; therefore, it is not surprising that private university students come from more affluent families (55-57). It is easier for students with higher financial resources to afford waterpipe. Three findings support the argument: Public university students who have a car are more likely to ever use waterpipe; a higher proportion of users in public versus private universities share waterpipe (as opposed to consuming it alone) ( $89.1 \%$ versus $85.6 \%$, significantly different at $10.1 \%$ level); and the average monthly spending on waterpipe is statistically significantly higher among private (42 TL) than public university students $(29.6 \mathrm{TL})$.

The findings of this research should be interpreted in light of several limitations: The sample includes only university students; therefore, non-student young adults are not covered. The sample is a convenience sample with participants recruited from three universities. Although the sample is large, it may not be representative of university students in the country. Ankara is the capital city with a higher than average per capita income and greater availability of outlets where the youth can access waterpipe. In smaller cities, the consumption pattern may be different. Also, the survey does not cover tobacco consumption in the family or the city where the student attended high school, both of which may play a role in initiation.

Despite these limitations, this study can motivate future quantitative and qualitative research to better understand waterpipe smoking behavior as well as its public health impact. It can guide regulatory efforts to curb waterpipe use during secondary education and later during university years when the risk continues. Additional tobacco control measures may be needed to guide private university students towards better health behavior.

\section{Conclusions}


Our findings indicate that waterpipe smoking is highly common among university students in Turkey. In our sample of university students, although the majority of ever users initiated before 18 , the risk of initiation continued after 18 . Private university students were found to be at a higher risk than public university students, mostly because of having easier access to financial resources and to waterpipe serving commercial venues.

As waterpipe tobacco use has become a major public health concern, policymakers, healthcare professionals, and researchers must act to closely monitor and control the practice. To satisfy the youth's need for socialization, their access to alternative activities, such as activities in sports clubs, social clubs, or youth centers may be facilitated. Additional youth-focused specific measures should be implemented to prevent private university students from the harms of waterpipe tobacco smoking based on the WHO Framework Convention on Tobacco Control.

\section{Abbreviations}

OR: Odds ratio; RRR: Relative Risk Ratio

\section{Declarations}

\section{Ethics approval and consent to participate}

Permission was obtained by the authors from the Ethics Committees of the respective universities prior to data collection (TOBB ETÜ Human Research Review Board Decision No. 2018 February 01-1;

Non-Interventional Clinical Research Ethics Board of Hacettepe University, 2018 April 10, G0 18/393-39). Students were given access to survey questions only after reading and agreeing to the informed consent form.

\section{Consent for publication}

Not applicable.

\section{Availability of data and materials}

The datasets generated and analyzed are currently not publicly available, because they are being used for another project, but are available from the corresponding author on reasonable request.

\section{Competing interests}

The authors have no competing interests.

\section{Funding}

Not applicable.

\section{Authors' contributions}


$\mathrm{AC}$ and $\mathrm{HÖ}$ contributed to the study design, data acquisition and analysis, drafting and critical revision of the manuscript. Both authors read and approved the final manuscript.

\section{Acknowledgements}

The authors are grateful to Esma Bişkin, who provided excellent research assistance. All remaining errors are the authors'.

\section{Reference}

1. Waziry R, Jawad M, Ballout RA, Akel M Al, Akl EA. The effects of waterpipe tobacco smoking on health outcomes: an updated systematic review and meta-analysis. Int J Epidemiol. 2017;46(1):32-43.

2. Akl EA, Gaddam S, Gunukula SK, Honeine R, Jaoude PA, Irani J. The effects of waterpipe tobacco smoking on health outcomes: a systematic review. Int J Epidemiol. 2010;39(March):834-57.

3. Robinson JN, Wang B, Jackson KJ, Donaldson EA, Ryant CA. Characteristics of Hookah Tobacco Smoking Sessions and Correlates of Use Frequency Among US Adults: Findings From Wave 1 of the Population Assessment of Tobacco and Health (PATH) Study. Nicotine Tob Res. 2018;20(6):731-40.

4. AkI EA, Gunukula SK, Aleem S, Obeid R, Jaoude PA, Honeine R. The prevalence of waterpipe tobacco smoking among the general and specific populations: a systematic review. BMC Public Health. 2011;11(1):1-12.

5. World Health Organization \& WHO Study Group on Tobacco Product Regulation (TobReg). Advisory note: Waterpipe tobacco smoking: health effects, research needs and recommended actions by regulators [Internet]. 2015. Available from: https://apps.who.int/iris/bitstream/handle/10665/161991/9789241508469_eng.pdf

6. Jawad M, Charide R, Waziry R, Darzi A, Ballout RA, Akl EA. The prevalence and trends of waterpipe tobacco smoking: A systematic review. PLoS One. 2018;13(2):1-20.

7. Bilir N. Successes and Challenges in Tobacco Control - Turkish Experience of 20 Years. Eurasian J Pulmonol. 2017;19:119-23.

8. Erbaydar NP, Bilir N, Yildiz AN. Knowledge, Behaviors and Health Hazard Perception Among Turkish Narghile (Waterpipe)-Smokers Related to Narghile Smoking. Pakistan J Med Sci. 2010;26(1):195-200.

9. Elbek O, Kılınç O, Aytemur ZA, Akyıldız L, Küçük ÇU, Özge C, et al. Tobacco Control in Turkey. Turkish Thorac J. 2015;16:141-50.

10. Global Youth Tobacco Survey. Küresel Gençlik Tütün Araştırması 2017 [Internet]. Republic of Turkey Ministry of Health. General Directorate of Public Health; Ankara.; 2017. Available from: https://hsgm.saglik.gov.tr/depo/birimler/tutun-mucadele-bagimlilik-db/duyurular/KGTA-2017_pdf.pdf

11. Poyrazoğlu S, Şarli Ş, Gencer Z, Günay O. Waterpipe (narghile) smoking among medical and non-medical university students in Turkey. Upsala J Med Sci ISSN. 2010;115(3):210-6.

12. Özcebe H, Doğan BG, İnal E, Haznedaroğlu D, Bertan M. Üniversite Öğrencilerinin Nargile İçme Davranışları ve Iliş̧kili Sosyodemografık Özellikleri [ Smoking Water Pipe Habits of University Students and Related Sociodemographic Characteristics ]. TAF Prev Med Bull. 2014;13(1):19-28. 
13. Nacar M, Cetinkaya F, Baykan Z, Yilmazel G, Elmalı F. Hazardous Health Behaviour among Medical Students: a Study from Turkey. Asian Pacific J Cancer Prev. 2015;16(17):7675-81.

14. Office of the Surgeon General. Preventing tobacco use among youth and young adults: a report of the surgeon general. United States. Public Health Service. National Center for Chronic Disease Prevention \& Health Promotion. Office on Smoking.; 2012.

15. Ranabhat CL, Kim C-B, Park MB, Jakovljevic M (Michael). Situation, Impacts, and Future Challenges of Tobacco Control Policies for Youth: An Explorative Systematic Policy Review. Front Pharmacol. 2019;10(September):1-13.

16. Roberts G. Education sector responses to the use of alcohol, tobacco and drugs (Vol. 10). UNESCO Publishing.; 2017.

17. Soule EK, Lipato T, Eissenberg T. Waterpipe tobacco-smoking: a new smoking epidemic among the young? Curr Pulmonol Reports. 2015;4:163-72.

18. The Tobacco Atlas. The Tobacco Atlas -Waterpipe [Internet]. 2021 [cited 2021 Mar 5]. Available from: https://tobaccoatlas.org/topic/waterpipe/

19. Council of Higher Education (Yükseköğretim Kurulu). Higher Education Statistics [Internet]. 2020. Available from: https://istatistik.yok.gov.tr/

20. Resmi Gazete. 2018-2019 Eğitim-Öğretim Yılında Yükseköğrenim Kurumlarında Cari Hizmet Maliyetlerine Öğrenci Katkısı Olarak Alınacak Katkı Payları ve Öğrenim Ücretlerinin Tespitine Dair Karar (Karar Sayısı: 2018/12007). 2018.

21. Turkish Statistical Institute (TurkStat). National Income Statistics. 2018.

22. Erdöl C, Ergüder T, Morton J, Palipudi K, Gupta P, Asma S. Waterpipe Tobacco Smoking in Turkey: Policy Implications and Trends from the Global Adult Tobacco Survey (GATS). Int J Environ Res Public Health. 2015;12:15559-66.

23. Tucktuck M, Ghandour R, Abu-rmeileh NME. Waterpipe and cigarette tobacco smoking among Palestinian university students: a cross-sectional study. BMC Public Health. 2018;18(1):1-12.

24. Tamim H, Terro A, Kassem H, Ghazi A, Khamis TA, Hay MMA, et al. Tobacco use by university students, Lebanon, 2001. Addiction. 2003;98:933-9.

25. Jradi H, Wewers ME, Pirie PP, Binkley PF, Ferketich AK. Cigarette and waterpipe smoking associated knowledge and behaviour among medical students in Lebanon. East Mediterr Heal J. 2013;19(10):8618.

26. Azab M, Khabour OF, Alkaraki AK, Eissenberg T, Alzoubi KH, Primack BA. Water pipe tobacco smoking among university students in Jordan. Nicotine Tob Res. 2010;12(6):606-12.

27. Khodadost M, Maajani K, Abbasi-ghahramanloo A, Naserbakht M, Ghodusi E, Sarvi F, et al. Prevalence of Hookah Smoking among University Students in Iran: A Meta-Analysis of Observational Studies. Iran J Public Health. 2020;49(1):1-13.

28. Jawad M, Choaie E, Brose L, Dogar O, Grant A, Jenkinson E, et al. Waterpipe Tobacco Use in the United Kingdom: A Cross-Sectional Study among University Students and Stop Smoking Practitioners. PLoS One. 2016;11(1):1-15. 
29. Salloum RG, Osman A, Maziak W, Thrasher JF. How popular is waterpipe tobacco smoking? Findings from internet search queries. Tob Control. 2015;24:509-13.

30. Hamadeh RR, Lee J, Abu-rmeileh NME, Darawad M, Mostafa A, Khalid AK, et al. Gender differences in waterpipe tobacco smoking among university students in four Eastern Mediterranean countries. Tob Induc Dis. 2020;18(December):1-12.

31. Dadipoor S, Kok G, Aghamolaei T, Heyrani A, Ghaffari M, Ghanbarnezhad A. Factors associated with hookah smoking among women: A systematic review. Tob Prev Cessat. 2019;5(26):1-11.

32. Villanti AC, Cobb CO, Cohn AM, Williams VF, Rath JM. Correlates of Hookah Use and Predictors of Hookah Trial in U.S. Young Adults. Am J Prev Med [Internet]. 2015;48(6):742-6. Available from: http://dx.doi.org/10.1016/j.amepre.2015.01.010

33. Nakkash RT, Khalil J, Afifi RA. The rise in narghile (shisha, hookah) waterpipe tobacco smoking: A qualitative study of perceptions of smokers and non smokers. BMC Public Health. 2011;11(315):1-9.

34. Niazi A, Shayan NA, Ozgur S, Joya SA, Ozcebe H. Waterpipe Smoking among Herat University Students: Prevalence, Attitudes, and Associated Factors. Addict Heal. 2020;12(4):235-43.

35. Maziak W. The waterpipe: time for action. Addiction. 2008;103:1763-7.

36. World Health Organization. Gender, women, and the tobacco epidemic. Samet JM, Yoon S-Y, editors. 2010.

37. Dar-odeh NS, Abu-hammad OA. The changing trends in tobacco smoking for young Arab women; narghile, an old habit with a liberal attitude. Harm Reduct J. 2011;8(24):2-5.

38. Makvandi Z, Mostafavi F, Bashirian S, Zamani-Alavijeh F, Kelishadi R. Sociocultural factors contributing to waterpipe tobacco smoking among adolescents and young adult women: a qualitative study in Iran. Int J Qual Stud Health Well-being [Internet]. 2021;16(1). Available from:

https://doi.org/10.1080/17482631.2020.1857043

39. Baheiraei A, Sighaldeh SS, Ebadi A, Kelishadi R, Majdzadeh SR. Psycho-social Needs Impact on Hookah Smoking Initiation among Women: A Qualitative Study from Iran. Int J Prev Med. 2015;6(79).

40. Labib N, Radwan G, Mikhail N, Mohamed MK, El M, Loffredo C, et al. Comparison of cigarette and water pipe smoking among female university students in Egypt. Nicotine Tob Res. 2007;9(5):591-6.

41. Amos A, Haglund M. From social taboo to "torch of freedom": the marketing of cigarettes to women. Tob Control. 2000;9:3-8.

42. Khalil J, Afifi R, Fouad FM, Hammal F, Jarallah Y, Mohamed M, et al. Women and Waterpipe Tobacco Smoking in the Eastern Mediterranean Region: Allure or Offensiveness. Women Health. 2013;53(1):10016.

43. Lee JJ, Yeung KCY, Wang MP, Thorne S. Arabian nights in Hong Kong: Chinese young adults' experience of waterpipe smoking. Tob Control. 2020;Epub ahead.

44. Akl EA, Ward KD, Bteddini D, Khaliel R, Alexander AC, Lotfi T, et al. The allure of the waterpipe: a narrative review of factors affecting the epidemic rise in waterpipe smoking among young persons globally. Tob Control. 2015;24:i13-21.

45. Akl EA, Jawad M, Lam WY, Co CN, Obeid R, Irani J. Motives, beliefs and attitudes towards waterpipe tobacco smoking: a systematic review. Harm Reduct J. 2013;10(12). 
46. Mugyenyi AEK, Haberer JE, O’Neil IO. Pleasure and practice: a qualitative study of the individual and social underpinnings of shisha use in cafes among youth in the UK. BMJ Open. 2018;8(e018989).

47. Ramji R, Nilsson M, Arnetz B, Wiklund Y, Arnetz J. Taking a Stand: An Untapped Strategy to Reduce Waterpipe Smoking in Adolescents. Subst Use Misuse [Internet]. 2019;54(3):514-24. Available from: https://doi.org/10.1080/10826084.2018.1521429

48. Sutfin EL, Mccoy TP, Reboussin BA, Wagoner KG, Spangler J, Wolfson M. Prevalence and correlates of waterpipe tobacco smoking by college students in North Carolina. Drug Alcohol Depend [Internet]. 2011;115(1-2):131-6. Available from: http://dx.doi.org/10.1016/j.drugalcdep.2011.01.018

49. Salloum RG, Lee J, Mostafa A, Abu-rmeileh NME, Hamadeh RR, Darawad MW, et al. Waterpipe Tobacco Smoking among University Students in Three Eastern Mediterranean Countries: Patterns, Place, and Price. Subst Use Misuse [Internet]. 2019;54(14):2275-83. Available from: https://doi.org/10.1080/10826084.2019.1645177

50. Colditz JB, Chu K, Switzer GE, Pelechrinis K, Primack BA. Online data to contextualize waterpipe tobacco smoking establishments surrounding large US universities. Health Informatics J. 2019;25(4):1314-1324.

51. Lee JJ, Wu Y, Wang MP, Yeung KC, Wong JY, Smith R. Waterpipe smoking among university students in Hong Kong: a cross-sectional study. BMC Public Health. 2020;20(543).

52. Jackson D, Aveyard P. Waterpipe smoking in students: Prevalence, risk factors, symptoms of addiction, and smoke intake. Evidence from one British university. BMC Public Health. 2008;8(174):1-5.

53. Arshad A, Matharoo J, Arshad E, Sadhra SS, Norton-Wangford R, Jawad M. Knowledge, attitudes, and perceptions towards waterpipe tobacco smoking amongst college or university students: a systematic review. BMC Public Health. 2019;19(439).

54. Hammal F, Wild TC, Nykiforuk C, Abdullahi K, Mussie D, Finegan BA. Waterpipe (Hookah) Smoking Among Youth and Women in Canada is New, not Traditional. Nicotine Tob Res. 2016;757-62.

55. Leslie LL, Brinkman PT. Student Price Response in Higher Education: The Student Demand Studies Student Price Response in Higher Education. J Higher Educ. 1987;58(2):181-204.

56. Heller DE. Student Price Response in Higher Education tE Student Price Response in Higher Education. J Higher Educ. 1997;68(6):624-59.

57. Caner A, Okten C. Economics of Education Review Higher education in Turkey: Subsidizing the rich or the poor ? Econ Educ Rev [Internet]. 2013;35:75-92. Available from:

http://dx.doi.org/10.1016/j.econedurev.2013.03.007

\section{Supplementary Files}

This is a list of supplementary files associated with this preprint. Click to download.

- WaterpipePublicPrivateUniversitiesSupplementaryMaterial18June2021.docx 